\title{
A Study of Corporate CSR Effects on Corporate Crisis Management
}

\author{
Jae-Min LEE ${ }^{1}$, Zhixuan QUAN ${ }^{2}$
}

Received: March 19, 2020. Revised: April 25, 2020. Accepted: May 01, 2020.

\begin{abstract}
Purpose: In modern corporate management, the establishment of a crisis management system that minimizes damage through measures used to respond to corporate crises is no longer an option. The importance of corporate reputation and brand asset management in modern enterprise management cannot be overemphasized and negative events that might arise from a number of different causes can cause brand crises. Research design, data and methodology: More than half of the questionnaire respondents were female (252 or $53 \%)$. More than a fourth of the respondents were aged $20(122$ or $26 \%)$ and the number of married participants was $196(41 \%)$. Of the participants, $32 \%$ (153) had graduated from college. Only $18 \%(87)$ were employees and the monthly household income was 121. In this study, we conducted factor analysis in order to extract the variables that may enhance the explanation capability of each variable. For the method of factor extraction, an Eigen value of at least 1 was used as was factor loading. An analysis was performed using the Cronbach's alpha coefficient to verify the reliability of the measurement scale. Results: First, the analysis of the impact of the social responsibility activities on brand image revealed that the social, economic, philanthropic, ethical, and environmental responsibility activities significantly affected brand image, but legal responsibility activities were not statistically significant. Second, the analysis of the impact of brand image on loyalty showed that brand image had a significant impact on loyalty. Third, the analysis of the impact of social responsibility activities on loyalty showed that they had a significant impact on loyalty. Conclu sions: The pro-social enterprise image is not only a brand asset that can be shared, but also a heavy proposition followed by a corresponding social responsibility, it will have to practice transparent corporate management based on clear principles through the establishment of various systems and the implementation of a strict code of conduct within the enterprise.
\end{abstract}

Keywords : Precedent CSR, Corporate Crisis Management, Event Intention, Backlight Effects, Boomerang Effect

JEL Classification Code M30, M 31, M39

\section{Introduction}

The DB insurance company's annual Yellow Carpet campaign attempts to bring the fact that the majority of children who are killed in traffic accidents are waiting at lights. This campaign installs yellow carpets in front of crosswalks. The company has joined with the Green Usan
Children's Foundation to expand the scope of the program in an effort to further protect the safety of children. Research has shown that this program has decreased drivers' speeds, on average, by $13 \mathrm{~km}$ and increased the company's sales. This study explores the various effects that successful proactive corporate social responsibility (CSR) activities could have on adverse events or information-induced
1 First Author. PhD Student, College of Business, SungKyunKwan University, Korea. Email: gregfoster@hanmail.net

2 Corresponding Author or Second Author, Professor, Dept. of alternative medicine, Kwangju women's university, Korea. Email:3700qzx@gmail.com

\footnotetext{
(c) Copyright: The Author(s)

This is an Open Access artide distributed under the terms of the Creative Commons Attribution Non-Commercial License (http://Creativecommons.org/licenses/by-nc/4.0/) which pemits unrestricted noncommercial use, distribution, and reproduction in any medium, provided the original work is properly cited.
} 
corporate crises. Typically, an organization's crisis is defined as a sudden event that contains time pressure demands and is likely to threaten the organization's future growth, profits, or survival (Sigurthorsson, 2012). The importance of corporate reputation and brand asset management in modern enterprise management cannot be overemphasized and negative events that might arise from a number of different causes can cause brand crises. Therefore, an enterprise must not only strive to build a strong brand, but also devise various countermeasures to preserve its value from decreasing in the event of a possible future corporate crisis (Zhou et al., 2018).

Several prior studies have identified the effectiveness of various CSR activity variables related to corporate crises as well as how to best use them. are relatively scarce on the subject of the liability of the adverse events that caused the crisis, namely. Two recent corporate crises, a diesel-powered operation by the Volkswagen Group and a major failure in control of the Middle East Respiratory Syndrome (MERS) by Samsung Medical Center, have also occurred in the future. Therefore, while this study is focused on whether a company intends to conduct positive CSR activities in order to negate possible negative future events, the assessment of the positive effects of a company's activities is reduced. Specifically, effective CSR communications and limitations were identified via the interactions that occurred as consumers' attitudes to attribution changes and consumers' perceptions of the hypocrisy of an entity is discriminatory.

\section{Theoretical Background}

\subsection{Effect of Leading CSR Activities}

A Crisis Management System (CMS) is an important part of corporate management and has been the focus of many practitioners and researchers (Solelhac, 2009). Studies that suggest a point-in-time response model based on the timing of a crisis have mainly focused on journalism, while Zhao et al. (2014) presented three stages of pre-, event- and poststage models. This study discusses the first (i.e., proactive) CSR effects implemented before negative events occur. The reputation of an enterprise can be defined as a holistic assessment that reflects whether people view an enterprise as skeptical or unconscionable (Sánchez \& Benito-Hernández, 2015). If a firm has a positive reputation, then it acts as defensively to minimize the damage to its image due to a negative event (Goala, 2007). This means that whether the entity has made a sincere effort to build good relationships with its consumers and stakeholders in the day before the event (Vanhamme et al., 2015) can affect its ability to secure justification in the event of a crisis.

One of the most utilized methods for building corporate legitimacy is the strategic use of CSR activities. Most prior studies have shown that the halo effect of conducting a proactive CSR activity can prevent corporate image damage in times of crises. Andreu et al. (2015) showed that if consumers accept a firm's CSR activities in a positive light, then the company will support them by applying external incentives that the cause of the crisis would be external. A study on the positive impact of CSO activities on a company's incentives (Kim, 2014), but only the suitability of the company's core business areas and CSR activities. This study focuses on whether a company intends to commit to a negative event, reaffirming the halo effect of prior CSR activities in the context of a corporate crisis, and identifies the adverse effects. In other words, companies that obtain pro-social corporate images through prior CSR activities suffer greater image damage than companies subject to the underlying effects of corporate hypocrisy in a crisis.

\subsection{Cognitive discord and the noble}

Consumers exposed to information about their CSR activities will assess whether the enterprise is actually performing its social responsibilities well and form a belief related to the firm's suitability as a pro-social entity (Mazereeuw-van et al., 2014). Consumers who encounter negative information resulting from a company's negligence experience a sense of disjunction due to differences in their existing social beliefs and the realities of the entity, which can be explained by the cognitive dissonance theory. According to Tezer et al. (2014), in the cognitive dissonance theory, people are motivated by psychological discomfort when faced with conflicting situations with their existing attitudes. When this cognitive dissonance is triggered, people try to resolve it in a variety of ways, including by showing a process of cognitive dissonance and reducing the importance of the cognitive dissonance that has caused it (Murillo \& Lozano, 2006). As such, when studying the impact of perceived incompatibility on corporate evaluations, the concept that consumers should be considered as one of the most important aspects of people. "Attributions" refer to the process of inferring the causes of a phenomenon. AngusLeppan et al. (2010) used their own logical and analytical methods to deduce the fundamental causes of the consequences of a situation or action, which are considered to be more external and environmental factors than an inherent problem. In addition, according to Rangan et al. (2015), other people's destructive behaviors negatively influence relationships. When deranged, the affected party showed that its response was discriminatory according to the incentive of the action and that its response varied depending on where to return the root cause of destructive behavior among the other, themselves and external environmental factors. A number of prior studies have been conducted to express the relationship between cerumen aspects and a 
firm's CSR activities. When considering this attribution theory in conjunction with a company's crisis situation, only a company that has accumulated pro-social images through active CSR activities are likely to minimize the damage to its corporate image. However, the justification process for such consumers is limited to cases in which the company has a low level of responsibility for the negative event. When the company's level of responsibility is high, the image is more likely to cause cognitive disintegration. As such. this study identifies a concept of organization called 'corporate hypocrisy' as a key factor for this phenomenon, shows the effect of a company's intention on the occurrence of a business crisis, and makes an interaction with a priori CSR.

\subsection{Perceived hypocrisy and event intent}

Perception of a person's hypocrisy usually occurs when a discrepancy exists between what he claims for himself and what is actually seen. The concept of brand personality (i.e., the concept of a company or brand established as an important trend in marketing research) is widely accepted in terms of the perception of the business and its brand, which also defines the company's hierarchy. A study by Buhmann (2016) showed that companies implementing proactive CSR strategies have seen a decline in consumer confidence in corporate hypocrisy, which, in turn, led to a fall in consumer confidence. This study suggests that this perception of 'corporate hypocrisy' may be differentiated by the intention of the entity in the process of the occurrence of the adverse events. Little research exists on the variables related to an entity's intent related to a negative event despite being important to the management of a crisis. This study defines the existence of an entity's intention as a mistake in different areas and expects it to represent different aspects of the attribution. According to Lim et al. (2017), people show negativity biases, biases, and biases. In other words, for information related to the morality of a particular subject, the diagnostic gender of negative information is higher than positive information, and for ability and ability-related information, positive information is given a higher diagnostic quality. This difference in diagnoses can also be attributed to the scarcity of information. For example, when recalling friends from school, information related to friends who were not often good or altruistic was more likely to be negative. This is highly diagnostic because each information is scarcity in the moral and competence areas as most people are more likely to be good than bad, and more than half of the people are categorized in areas where grades and motor skills were poor. In regard to this study, if a negative event occurs without the permission of the entity, then the crisis is regarded as a matter of ability, such as failing to have control or neglect of care, rather than a moral problem. This does not significantly change the existing image of the entity as it is not subject to highly diagnostic information, and the decline in the assessment of the entity is relatively low as the external incentives of the consumers are applied to entities that obtain pro-social reputations through CSR activities. On the other hand, if a negative event occurs with the permission of the entity, then the crisis is considered to be a moral issue and perceived by consumers to be highly diagnostic information. Thus, in the case of intentional negligence, consumers who fail to resolve the cognitive dissonance are expected to apply internal incentives to the entity, and those that have a prosocial reputation are expected to have a larger adverse effect due to perceived hypocrisy.

\section{Research Method}

The purpose of this study is to explain the phenomenon of CSR activities in which the image as a pro-social enterprise of the effect that can occur when a CSR occurs can be more counterproductive to a decline in the valuation of a company. Explore the interaction in which the pattern of consumer behavior changes according to the company's judgment on the negative event.

Table 1: Regression Analysis

\begin{tabular}{|c|c|c|c|c|l|}
\hline Source & DF & $\begin{array}{c}\text { Sum of } \\
\text { Squares }\end{array}$ & $\begin{array}{c}\text { Mean } \\
\text { Square }\end{array}$ & F Value & Pr $>$ F \\
\hline Model & 8 & 3188.67 & 398.58 & 55.72 & $<.0001$ \\
\hline Error & 15 & 107.29 & 7.15 & & \\
\hline $\begin{array}{c}\text { Corrected } \\
\text { Total }\end{array}$ & 23 & 3295.96 & & & \\
\hline \multicolumn{2}{|c|}{ R-Square } & \multicolumn{2}{|c|}{ Coeff Var } & Root MSE & \multicolumn{2}{|c|}{ SALES Mean } \\
\hline 0.97 & 2.25 & 2.67 & \multicolumn{2}{|c|}{118.79} \\
\hline Source DF & Type I SS & $\begin{array}{c}\text { Mean } \\
\text { Square }\end{array}$ & F Value & Pr $>$ F \\
\hline R & 5 & 21.21 & 4.24 & 0.59 & 0.7058 \\
\hline ADS & 3 & 3167.46 & 1055.82 & 147.61 & $<.0001$ \\
\hline
\end{tabular}

Table 2: ANOVAAnalysis

\begin{tabular}{|c|c|c|c|c|c|}
\hline Source & DF & $\begin{array}{c}\text { Sum of } \\
\text { Squares }\end{array}$ & $\begin{array}{c}\text { Mean } \\
\text { Square }\end{array}$ & $\begin{array}{c}\mathbf{F} \\
\text { Value }\end{array}$ & Pr $>$ F \\
\hline Model & 13 & 8.46 & 0.65 & 6.30 & $<.0001$ \\
\hline Error & 36 & 3.72 & 0.10 & & \\
\hline $\begin{array}{c}\text { Corrected } \\
\text { Total }\end{array}$ & 49 & 12.18 & & & \\
\hline R-Square & \multicolumn{2}{|c|}{ Coeff Var } & Root MSE & \multicolumn{2}{|c|}{ Y Mean } \\
\hline
\end{tabular}




\begin{tabular}{|c|c|c|c|c|c|c|}
\hline \multicolumn{2}{|c|}{ Source } & DF & $\begin{array}{c}\text { Sum of } \\
\text { Squares }\end{array}$ & $\begin{array}{l}\text { Mean } \\
\text { Square }\end{array}$ & $\begin{array}{c}F \\
\text { Value }\end{array}$ & $\operatorname{Pr}>\mathrm{F}$ \\
\hline \multicolumn{2}{|c|}{0.69} & & 55.42 & 0.32 & \multicolumn{2}{|c|}{0.58} \\
\hline Source & DF & & Anova SS & $\begin{array}{l}\text { Mean } \\
\text { Square }\end{array}$ & $\begin{array}{c}F \\
\text { Value }\end{array}$ & $\operatorname{Pr}>\mathrm{F}$ \\
\hline $\mathrm{R}$ & 9 & & 2.58 & 0.29 & 2.77 & 0.0141 \\
\hline ITEM & 4 & & 5.88 & 1.47 & 14.23 & $<.0001$ \\
\hline
\end{tabular}

\section{Conclusions}

The corporate reputation gained through the establishment of a pro-social image confirmed the possibility that it could serve as a defense against the decline in corporate valuation in special circumstances. With regard to the effectiveness of CSR activities, this study looked at the various effects that pro-social enterprise images formed through preceding CSR activities could have in the event of a corporate crisis. It can be assessed that the intent of an entity is an original part of this study that differentiates itself from existing studies that have expanded the flow of that research by suggesting that each issue of morality and competence is perceived by consumers and that differences in the diagnostic nature of information may result in different aspects. These results provide an indication that they can be a key part of an effective CSR practice in general and special circumstances related to an enterprise, with an understanding of the constitutive concepts that have not been addressed much in previous CSR-related prior studies. The pro-social enterprise image is not only a brand asset that can be shared, but also a heavy proposition followed by a corresponding social responsibility, it will have to practice transparent corporate management based on clear principles through the establishment of various systems and the implementation of a strict code of conduct within the enterprise.

\section{References}

Adam, A. M., \& Shavit, T. (2008). How can a ratings-based method for assessing corporate social responsibility (CSR) provide an incentive to firms excluded from socially responsible investment indices to invest in CSR? Journal of Business Ethics, 82(4), 899-903

\section{Research Hypotheses}

Hypothesis 1 of this study identifies the positive effect on consumers of pro-social enterprise images formed through prior CSR activities in the case of general circumstances in prior studies.

H1: In the case of an assessment of an enterprise in general circumstances, there will be a higher corporate assessment than those that have implemented pro-social CSR activities.

H2: In the case of an assessment of an entity in a particular situation, a lower enterprise assessment will appear compared to an unintended one.

H3: In the case of an assessment of an enterprise in general circumstances, a higher enterprise assessment will appear compared to the conditions under which the pro-social CSR activity information is presented.

Andreu, L., Casado-Diaz, A. B., \& Mattila, A. S. (2015). Effects of message appeal and service type in CSR communication strategies. Journal of Business Research, 68(7), 1488-1492.

Angus-Leppan, T., Metcalf, L., \& Benn, S. (2010). Leadership styles and CSR practice: An examination of sensemaking, institutional drivers and CSR leadership. Journal of Business Ethics, 93(2), 189-203.

Bocquet, R., Le Bas, C., Mothe, C., \& Poussing, N. (2017). CSR, innovation, and firm performance in sluggish growth contexts: A firm-level empirical analysis. Journal of Business Ethics, 146(1), 241-251.

Buhmann, K. (2016). Public regulators and CSR: The 'social licence to operate' in recent United Nations instruments on business and human rights and the juridification of CSR. Journal of Business Ethics, 136(4), 699-702.

Goala, G. (2007). Customer switching resistance (CSR): The effects of perceived equity, trust and relationship commitment. Journal of Service Management, 18(5), 510-522.

Jiang, F., Zalan, T., Tse, H. H., \& Shen, J. (2018). Mapping the relationship among political ideology, CSR mindset, and CSR strategy: A contingency perspective applied to Chinese 
managers. Journal of Business Ethics, 147(2), 419-432.

Kim, Y. (2014). Strategic communication of corporate social responsibility (CSR): Effects of stated motives and corporate reputation on stakeholder responses. Public Relations Review, 40(5), 838-840.

Lim, J. S., \& Greenwood, C. A. (2017). Communicating corporate social responsibility (CSR): Stakeholder responsiveness and engagement strategy to achieve CSR goals. Public Relations Review, 43(4), 768-773.

Mazereeuw-van der, D. S. C., \& Graafland, J. (2014). Religiosity, CSR attitudes, and CSR behavior: An empirical study of executives' religiosity and CSR. Journal of Business Ethics, 123(3), 437-449.

Murillo, D., \& Lozano, J. M. (2006). SMEs and CSR: An approach to CSR in their own words. Journal of Business Ethics, 67(3), 227-236.

Öberseder, M., Schlegelmilch, B. B., \& Gruber, V. (2011). Why don't consumers care about CSR: A qualitative study exploring the role of CSR in consumption decisions. Journal of Business Ethics, 104(4), 449-457.

Oh, H., Bae, J., \& Kim, S. J. (2017). Can sinful firms benefit from advertising their CSR efforts? Adverse effect of advertising sinful firms' CSR engagements on firm performance. Journal of Business Ethics, 143(4), 643-653.

Pomering, A., \& Dolnicar, S. (2009). Assessing the prerequisite of successful CSR implementation: Are consumers aware of CSR initiatives? Journal of Business Ethics, 85(2), 285-297.

Rangan, K., Chase, L., \& Karim, S. (2015). The truth about CSR: Most CSR programs don't pursue "shared value" -and needn't.
Harvard Business Review, 93(1-2), 40.

Sánchez, P. E., \& Benito-Hernández, S. (2015). CSR policies: Effects on labour productivity in Spanish micro and small manufacturing companies. Journal of Business Ethics, 128(4), $705-714$.

Sigurthorsson, D. (2012). The Icelandic banking crisis: A reason to rethink CSR? Journal of Business Ethics, 111(2), 147-152.

Singhapakdi, A., Lee, D. J., \& Sirgy, M. J. Senasu. (2015). The impact of incongruity between an organization's CSR orientation and its employees' CSR orientation on employees' quality of work life. Journal of Business Research, 68(1), 6064.

Solelhac, V. (2009). Impact of CSR communication strategies on attitude change after a crisis. Advances in Consumer Research, 36,1060 .

Tezer, A., Bodur, H. O., \& Grohmann, B. (2014). The CSR surprise Effect: When unexpected CSR activity enhances brand evaluations. Advances in Consumer Research, 42, 704-705.

Vanhamme, J., Swaen, V. R., \& Berens, G. J. (2015). Playing with fire: Aggravating and buffering effects of ex ante CSR communication campaigns for companies facing allegations of social irresponsibility. Marketing Letters, 26(4), 565-571.

Zhao, M., Tan, J., \& Park, S. H. (2014). From voids to sophistication: Institutional environment and MNC CSR crisis in emerging markets. Journal of Business Ethics, 122(4), 655-664.

Zhou, Z., \& Ki, E. J. (2018). Exploring the role of CSR fit and the length of CSR involvement in routine business and corporate crises settings. Public Relations Review, 44(1), 75-81. 